epithelium is encountered. The lungs exhibit areas of hemorrhage into the alveoli, and in many of these there has been a desquamation of the alveolar epithelium. Sometimes the desquamated epithelial cells are quite normal in appearance, while at others they have fragmented nuclei. The collections of lymphoid cells around the medium-sized and larger bronchi show, however, more cells, the nuclei of which have suffered in this way.

The blood-vessels of the tissues generally contain fewer leucocytes in this instance than in those cases in which the bacilli were introduced beneath the skin. By the latter method an intense local inflammatory process is provoked, associated with the emigration of large numbers of polynuclear leucocytes. In the former, in which the filtrate, free from organisms, is used for inoculation, the local process is reduced to nil, there is no emigration of leucocytes, and the disease is general from its inception. This difference is sufficient to account for the occurrence of leucocytosis in the one and its absence in the other case.

It may be considered as established now that the toxic products and not the bacilli themselves invade the tissues in diphtheria. This fact would at once suggest that the general lesions (those produced at a distance from the seat of inoculation in animals, and the situation of the local process in human beings) were the effects of the soluble poison diffused through the body. Hence, it was desirable to demonstrate this assumption experimentally; and it is not unimportant to know that the lesions in the tissues produced by bacilli and the toxic principle on the one hand, and by the toxic principle alone on the other, are in perfect correspondence with each other. And, moreover, it would seem not to be superfluous to emphasize the occurrence of definite focal lesions in the tissues of the body, produced by a soluble poison circulating in the blood.

\section{DESCRIPTION OF A SUPPOSED NEW SPECIES OF STORERIA FROM FLORIDA, STORERIA VICTA.}

THE species of Storeria here to be described as new was found in the alimentary canal of a specimen of Elaps fulvius, which was taken on the banks of the Oklawaha River, Florida, by one of my students, Mr. H. T. Mann. The Storeria had been swallowed head first, and had been somewhat digested anteriorly, but the hinder half or two-thirds of the body had undergone little change. Sufficient traces of the cephalic plates were left to show that the latter were those of the genus Storeria, the loreal being certainly absent. About twenty-five of the anterior ventral plates were missing, but the number of these could be determined from the vertebræ there exposed.

The dorsal scales are in fifteen rows. When the scales of the middle of the back are compared under the microscope carefully with those of a specimen of Storeria dekayi of the same size, the former are plainly of a greater proportional width. Whether or not this will hold true in all cases I can not, of course, say. The ventral plates number 146 , counting from the angle of the jaw. There are 60 pairs of subcaudal scales. The anal plate is divided. The total length of the specimen is 14 inches, of which 3 are tail.

The color is gray above, with a tinge of yellow. In the middle of the back are very faint indications of a clay. colored band. This occupies the median three rows of scales. The next row of scales on each side is occupied by an indistinct dusky line and by a row of black specks. These lie distant from one another about the length of two scales.
Lower down on the sides the color becomes paler, but another dusky streak is seen lying partly on the lower row of scales and partly on the out-ends of the ventral plates. The belly is pale yellow, with a row of small, but very distinct, black spots along each side. There is a single spot on each end of each ventral plate, lying about half-way from the middle line of ${ }^{\circ}$ the belly and the outer end of the plate. A few smaller, irregularly placed spots are also seen. The under surface of the tail is plain yellowish white. Storeria dekayi sometimes has black dots on the abdomen, but they are irregularly scattered, or at most do not form rows the whole length of the belly.

This species appears to differ from Storeria dekayi in the smaller number of dorsal scales (15 instead of 17 ), in the greater proportional width of the scales, in the somewhat greater number of ventral plates, and in the presence of the two rows of spots on the abdomen. As to the number of ventrals, Mr. Samuel Garman ("Serpents of N. A.," p. 31) states that they vary from 120 to 138 . He mentions, however, a specimen from Jalapa, Mexico, which had 145 ventrals. It is possible that the animal which $I$ here describe as new is a specimen of $S$. dekayi with a smaller number of scales than usual, but until there is other evidence of this, it seems better to regard it as different.

From S. occipitomaculata my specimen differs in having a considerably larger number of ventrals and subcaudals than have yet been attributed to that species, in the presence of the rows of ventral spots, and in size. The relations of the specimen appear to lie evidently with $S$. dekayi.

The oviducts of the specimen contained a dozen eggs, each somewhat more than a quarter of an inch in length. The coverings of the eggs are extremely thin, from which I infer that the animal brings forth its young alive. This is the case with $S$. dekayi, and probably with the other species of the genus.

The specimen here described will be deposited in the $\mathrm{Na}$ tional Museum at Washington.

Irvington, Ind., April 2.

\section{THE HIGHER EDUCATION OF THE DEAF.}

THE following letter was recently addressed to President E. M. Gallaudet of the National College at Washington, by Mr. A. L. E. Crouter, principal of the Pennsylvania Institution for the Deaf and Dumb:

President E. M. Gallaudet, Ph.D., LL.D.

My Dear Sir: Since my return from the meeting of the Board of the American Association to Promote the Teaching of Speech to the Deaf, held in your city in January, my thoughts have frequently recurred to a matter of much interest to the association, and, to my mind, of vital importance to your college work, namely, the introduction of oral methods in the instruction of a portion, at least, of the young men and women who come to you for a higher education than the primary schools of the country are able to afford them.

And, in venturing to address you formally upon the subject, I beg you to believe that I am not impelled by any spirit of captious criticism, nor by any desire to intermeddle with the affairs of your excellent and well conducted school, but simply and solely to suggest for your consideration a step which I sincerely believe will, if put into effect, greatly promote and extend the usefulness of the college whose affairs you have so long and so ably directed.

As you are aware, Mr. Greenberger, at our meeting in Washington, brought up the question of oral instruction (recitations) for oral students at Kendall Green, maintaining that, in a school supported by the national government, equal educational advan- 
tages and privileges should be accorded to the orally taught deaf and to the manually taught deaf, pursuing oral methods in the education of the former, manual methods with the latter. In bringing up the subject, Mr. Greenberger disclaimed any unfriendly feeling towards the college, and $\mathrm{I}$ wish to do him the justice to state that he had no desire to embarrass you in your noble work, but, moved by a sense of justice, he felt that the time had come when the association should take a stand in favor of the higher oral education of the orally taught deaf of the country, in the college at Kendall Green if possible, if impossible, then outside in a separate school. Now, while the question was disposed of, for the time being at least, in a way that exhibited the kindliest feeling toward you and your college work, I feel that sooner or later it will have to be met and disposed of to the advantage of the college or to its disadvantage, strengthening it if an oral department be added, weakening it if, refused in what they believe to be just demands, the friends of higher oral instruction for the deaf establish a separate college for their higher education. The oral instruction of the deaf, whether wisely or unwisely, is unquestionably commanding increased public attention and public sympathy, and the college that seeks to provide the highest and best educational facilities for the deaf as a class should stand ready to meet every reasonable demand. The number of orally taught deaf is constantly increasing, they are seaking higher instruction than the primary schools afford, where sball they obtain it?

They hesitate, and object, and refuse when directed to Kendall Green, not because it is not a good school, nor because its professors are not competent men, but because of a well-founded fear that that which they have spent much time and labor in gaining, namely, their speech and their ability to read speech; may be very seriously impaired. Shall this class of deaf-mutes come to Kendall Green to profit by instruction at the bands of its able and experienced professors, greatly strengthening the power and influence of the college, or shall they be driven to another school?

To me, interested as I am in the success of the only college for the deaf in the world, this is a most important question, and $I$ believe it will receive the careful consideration that its importance demands at your hands. The formation of an oral department with the means you have at your command should not present any serious difficulties, nor prove seriously harrassing to your wellordered college work. For material you would have the best from every school in the land, and for support you would have the sympathy and active influence of every friend of the deaf throughout the world.

A. L. E. Crouter

March 5.

\section{NOTES AND NEWS.}

THE faculty of Cornell Unirersity has been invited to send representatives to take part in the Tercentenary Festival of the Unirersity of Dublin, next summer, and has accepted, Professor Corson going as its representative. Dr. Thurston has receiced a personal invitation from the Unirersity of Dublin for the same occasion, and is expected, if he should be able to go, to remain in Dublin as the guest of Dr. Lucius O. Hutton of Fitzwilliam Place.

- The second number of 1892 of the Bulletin of the Ohio Experiment :Station summarizes the experience of the station in the culture of mangolds and sugar beets. Mangolds have been grown on the station farm for ten or twelve years past, to serve as food for the dairy cows; twelve to fifteen tons per acre being an ordinary yield. The beets are eaten with great relish by the cows, they cause an increased flow of milk, and the milk is thought to be of a better quality. The milk from this dairy is sold direct to consumers, and these have claimed that they could tell when beet feeding began in the fall by the improved flavor of the milk. In 1891 a number of varieties of sugar beets were grown alongside the mangolds; it was found that the sugar beets were considerably less productive than the mangolds, Jielding but seven to nine tons per acre, against twelve to twenty tons for the mangolds. The sugar beets, howerer, showed on analysis about six per cent of sugar, while the mangolds showed but three per cent. The labor- cost of producing an acre of beets is from thirty to forty dollars, as grown at the station, where they are planted in rows sufficiently wide to admit of horse culture. By planting in rows only half as far apart the crop minht largely be increased, but the cost of cultivation would also be increased. In a bullet in issued a year ago by the Chemical Division of the United States Department of Agriculture, a table is giren showing that the average cost of manufacture in 113 German beet sugar factories in 1889-90 was nearly $\$ 3$ per ton of beets. If it were possible to raise an average crop of fifteen tons per acre of sugar beets in Ohio at a cost of $\$ 30$ per acre, or $\$ 2$ per ton, or to manufacture them at a cost of $\$ 3$ per ton, the total cost for production and manufacture would be $\$ 75$ per acre. Such a crop would yield 1,800 pounds of sugar, at the rate shown by the station analysis, worth $\$ 72$ at four cents per pound, thus leaving no margin whatever to either producer or manufacturer to cover the losses from bad seasons on the farm or in the factory. It is true the present bounty would afford this margin; but the bounty ends with 1895, unless renewed, and its future is very uncertain. Sugar beets grown in the dry climate and on the rich soils of Nebraska and Iowa show an average of about thirteen per cent sugar, or more than twice that found at the Ohio station, thus following the well-known law that the sugar beet reaches its highest development in northern latitudes. Bets grown in northern Ohio would probably show a higher per cent of sugar than has been found at the station, but it is extremely doubtful if the culture and manufacture of sugar beets can be 'made profitable in any part of Ohio in competition with the more favored regions of the North-west and of California, and the Experiment station would advise Ohio farmers to be very cautious about entering upon any large undertaking in sugar beet culture. There are probably spots in northern Ohio where spring wheat could be grown, and it is possible cotton might mature in sheltered coves in Lawrence County; but it would hardly be advisable for the farmers of either section to enter into competition with the spring wheat growers of the North-west or the cottor planters of the Gulf States.

- The Oriental History Society of Altenburg will celebrate in the autumn of 1892 the seventy-fifth anniversary of its establishment, and will take advantage of this opportunity to pay trihute to three of the honorary members of the Society, by the erection of a simple, worthy monument in the capital city of Altenburg. They are Christian Ludwig Brehm, his son, Alfred Brehm, and Professor Schlegel, who died at Leyden. The researches of these three men in zoology, and particularly in ornithology, are known, not only among their associates, but throughout the world, and deserve that their memory should be honored. A committee, consisting of Prince Moritz of Saxe-Altenburg; Prof essor Dr. Blasius, Braunschweig; Dir. Professor Flemming, Altenburg; Major A. v. Homeyer, Greifswald; Hugo Koehler, privy-councillor of commerce, Altenburg; Dr. Keopert, Altenburg; Professor Dr. Liebe, privy-councillor, Gera; Professor Dr. Pilling, Altenburg; Dr. Reichenow, Berlin; Dr. Rothe, privy-councillor of medicine, Altenburg; Chevalier von Tschusi zu Schmidhoffen, Hallein: Dr. Voretzsch, Altenburg; and Dr. Leverkuhn, Munich, under the patronage of His Highness, Prince Moritz of Saxe-Altenburg, also an honorary member of the society, solicits contributions from the friends of these eminent scientists, for the purpose of aiding in the erection of the proposed memorial. It is respectfully requested that contributions be forwarded to Hugo Koehler, privy-councillor of commerce, in Altenburg, and that inquiries and letters be addressed to Dr. Koepert, in Altenburg.

- Mr. R. H Scott delivered a lecture at the Royal Institution on March 18, on a subject of much importance to England, viz.: "Atlantic Weather and its Connection with British Weather." He pointed out, says Nature, that less than a quarter of a century ago, before synchronous charts were in vogue, it would have been impossible to have traced a storm across America and the Atlantic to Britain's coasts; but this can now be done with considerable certainty. The broad principles which govern the weather system of the Atlantic were shown on two diagrams exhibiting the mean pressure. and the regions of greatest disturbance of temperature, on the globe in our winter. The latter chart showed that, at that 